\title{
E-Waste Supply Chain in Mexico: Challenges and Opportunities for Sustainable Management
}

\author{
Samantha E. Cruz-Sotelo ${ }^{1, *}$, Sara Ojeda-Benítez ${ }^{2}$, Jorge Jáuregui Sesma ${ }^{2}$, \\ Karla I. Velázquez-Victorica ${ }^{1}$, Néstor Santillán-Soto ${ }^{2}$, O. Rafael García-Cueto ${ }^{2}$, \\ Víctor Alcántara Concepción ${ }^{3}$ and Camilo Alcántara 4 \\ 1 Facultad de Ingeniería, Universidad Autónoma de Baja California 1, Mexicali 21280, Mexico; \\ isabel.velazquez@uabc.edu.mx \\ 2 Instituto de Ingeniería, Universidad Autónoma de Baja California 2, Mexicali 21280, Mexico; \\ sara.ojeda.benitez@uabc.edu.mx (S.O.-B.); jaureguisesma@gmail.com (J.J.S.); \\ nsantillan@uabc.edu.mx (N.S.-S.); rafaelcueto@uabc.edu.mx (O.R.G.-C.) \\ 3 Instituto Nacional de Ecología y Cambio Climático 3, Mexico City 04530, Mexico; \\ victor.alcantara@inecc.gob.mx \\ 4 División de Ingenierías, Universidad de Guanajuato 4, Guanajuato 36000, Mexico \\ camiloalcantara@gmail.com \\ * Correspondence: samantha.cruz@uabc.edu.mx; Tel.: +52-686-566-4270 \\ Academic Editor: Vincenzo Torretta \\ Received: 22 February 2017; Accepted: 22 March 2017; Published: 27 March 2017
}

\begin{abstract}
Electronic waste is a widespread environmental problem. From all waste streams, e-waste is registering one of the largest growing rates (between 3\% and 5\%). In Mexico, the e-waste recovery system comprises a mix of formal and informal sectors not well known to date. The goal of this article was to analyze electronic waste in Mexico through the active actors in the recovery chain. This article presents the evolution of studies on electronic waste in Mexico. The legal regulations and public policies were analyzed, as were the existing practices of electronic waste handling, and some challenges facing this country for waste flow management. A management model is proposed which highlights components that must be considered in the model and the opportunities and challenges to transition from an unbundled handling, which still has practices that lack environmental and technical support, to sustainable management.
\end{abstract}

Keywords: WEEE management; legislation; plan; recovery; finance system

\section{Introduction}

With the arrival of the information-based society come high consumption rates of electrical and electronics equipment (EEE). In fact, waste electrical and electronic equipment (WEEE) growing rates are usually three times faster than urban waste, and the WEEE increase rate, globally, is estimated between $3 \%$ and $5 \%[1,2]$.

Electronic devices have facilitated many tasks in several areas. However, the industry tends to promote an insatiable appetite for newer and more attractive devices in the public. This promotion towards EEE renovation also creates a growing environmental problem, associated with electronic waste management [3-5]. EEE renovation also influences the promotion of technological obsolescence. It is important to highlight that technological obsolescence periods are becoming shorter, and the acquisition cost reflects a downward trend. Technological obsolescence is an incremental phenomenon for our information- and knowledge-based society [6,7]. In summary, the EEE industry is responsible for $10 \%-20 \%$ of the global environmental impact related to the depletion of non-renewable resources [8,9]. As a consequence, decision-makers have the challenge of handling the waste of electrical and electronic devices in a sustainable and responsible manner. 
In 2014 around 42 million tons of electrical and electronic wasted devices were generated worldwide [10,11]. A recent study focused on the search for solutions to the e-waste problem (StEP), predicting a $33 \%$ increment for 2017, which is equivalent to 65.4 million tons [12].

Some electronic devices have a useful life pre-established by the producer. After some time, the equipment must be replaced again. This is what is known as the product life cycle, consisting of establishing a functional period for the product. Thus, in home appliances and digital devices, manufacturing includes the programmed end of the product life cycle. Setting an end of the product life cycle effectively stops the EEE after a specific number of uses or at specific times, forcing customers to buy new products. The objective of this producer's practice is to assure a circulation of merchandise, gaining more benefits. Thus, in the EEE industry, environmental considerations and natural resource conservation are last on the agenda of priorities [13]. The end of the product life cycle and its replacement period is known as the phase of obsolescence or technological obsolescence.

Obsolescence is a concept that considers customers' influence by fad, marketing, and consumption culture to replace their electronic equipment. The concept is designed to appeal mainly to the intrinsic desire from the customer to have a better lifestyle. This practice is associated with three types of obsolescence promoted by manufacturers: functional obsolescence, when a product substitutes another with its superior functionality; quality, when a product becomes obsolete due to poor program function; and convenience, which occurs when an electronic device that is still completely functional and with no better substitute stops being desired due to mode or style. Technological obsolescence is considered to improve the circulation of merchandise, and, when it is present, puts a strong influence on the users in order to replace their electronic devices. This behavior directly influences the high generation of WEEE (Figure 1).

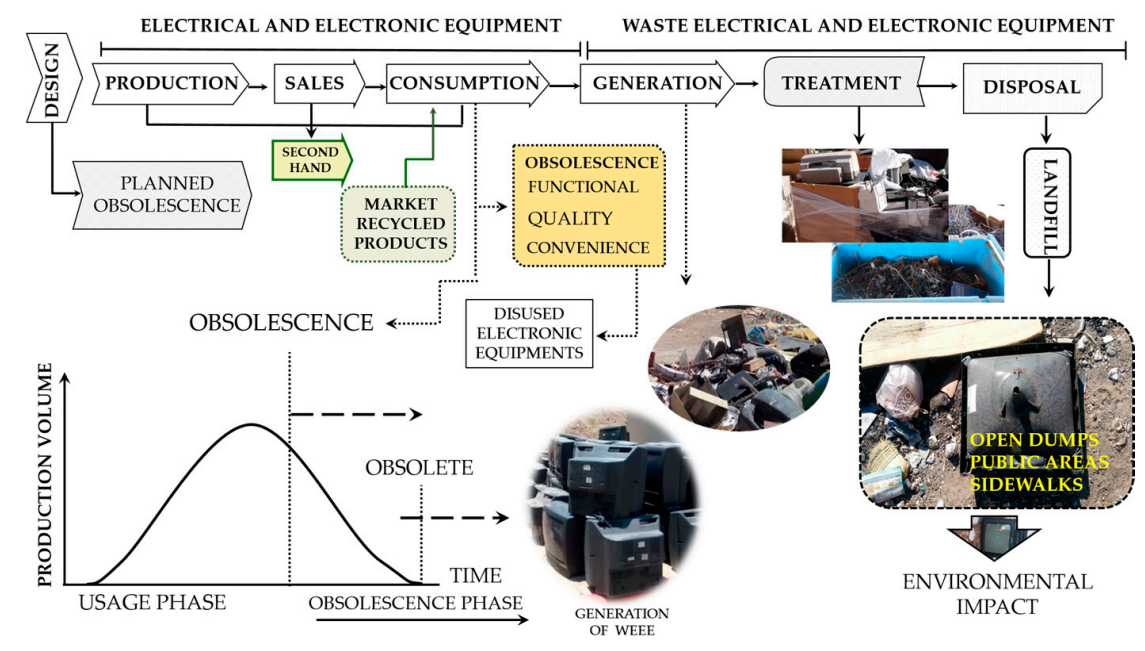

Figure 1. Obsolescence in life cycle of electrical and electronic equipment.

Worldwide, WEEE constitutes one of the most problematic waste types in streams and water bodies. For that reason, it is important to estimate with precision the amount of waste produced and managed in each phase of a product's life cycle. An accurate estimation will help us be ready and face associated problems when handling WEEE, and will allow us to improve the accountability of its management in a sustainable way. Another problem is that WEEE comprises a complex mix of different materials. WEEE can be composed of hazardous substances, such as lead, mercury, biphenyls, diphenyl ethers, brominated flame retardants, and other coolants, many of them with potential environmental impacts; however, WEEE also contains valuable substances, such as nonprecious metals (iron, steel, copper, aluminum, among others), precious metals (for instance, gold, silver, platinum, palladium), and plastics $[3,14,15]$. In Latin American countries, there are no WEEE management systems. Therefore, we ought to start our own efforts to address the problem. However, it is necessary 
to tackle it using a management systems approach, where all involved actors are in charge, committed, and accountable along the cycle.

Some EEE ends up in common garbage disposals and already-contaminated fields or landfills by the end of its life cycle. Those disposal sites are, thus, exposed to a collection of chemical substances and heavy metals contained in the EEE, such as beryllium, chromium, cadmium, arsenic, selenium, antimony, mercury, and lead. This exposure is highly hazardous and, to ameliorate environmental impacts, it ought to require appropriate disposal [16]. It should be mandatory to set up a sustainable treatment plan for collecting those EEEs in disuse.

The largest volumes of EEE generation are focused on the production of small equipment (Figure 2). Developing countries have strong potential in terms of recovering raw material from WEEE; however, lack of legislation, specific guidelines, and infrastructure make it difficult to manage recovery and utilization of components in the market.

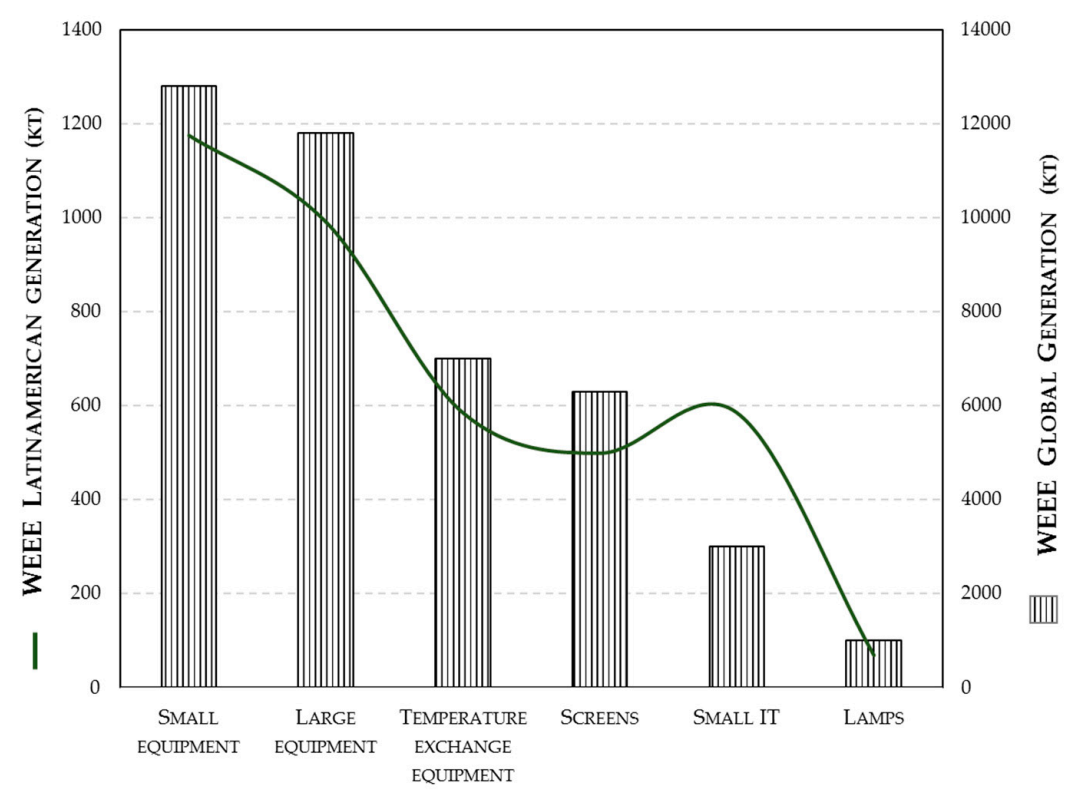

Figure 2. Electronic waste generation worldwide and in Latin America. Source. Prepared by the authors based in [10].

The fast technological development growth, the constant updates of electronic products, and the reduction in their useful life lead us to face challenges of e-waste disposal. WEEE disposal turns out to be an important and controversial topic, not only for the recycling industry, but also for all of the internationally involved actors. In this article, we used Mexico as an example to analyze the role of actors in the WEEE recovery chain.

\section{Electronic Waste in the Waste Stream System in Mexico}

The Mexican waste management system shows different pathways for each source of waste. In order to locate the e-waste, we schematize the Mexican waste management system in order to include the waste sources, their collection and disposal pathways, the recyclable collection components, the recovery actors and markets, as well as their management and disposal responsibility levels (Figure 3).

Figure 4 presents a diagram that shows studies realized in Mexico according to the issues and dimensions of the problem. The studies started in 2006, presenting different actions that have been undertaken to realize the WEEE generation at national and regional levels, as well as proposals for reference frameworks for the management of this waste stream. 
In the first national diagnosis of electronic waste generation, it was estimated that 257,000 tons of waste was generated in 2006, indicating 1.5-1.6 kg/year per capita [17]. This estimation provided a first approximation to know the magnitude of the waste generation problem in México. However, there are still gaps of precise information about consumption patterns, and particularly of alternatives to storage and the final disposal of electronic waste. Roman [18] indicates that, despite the lack of a formal infrastructure for the management of waste in its different stages, the informal market is a reality in WEEE management in Mexico.

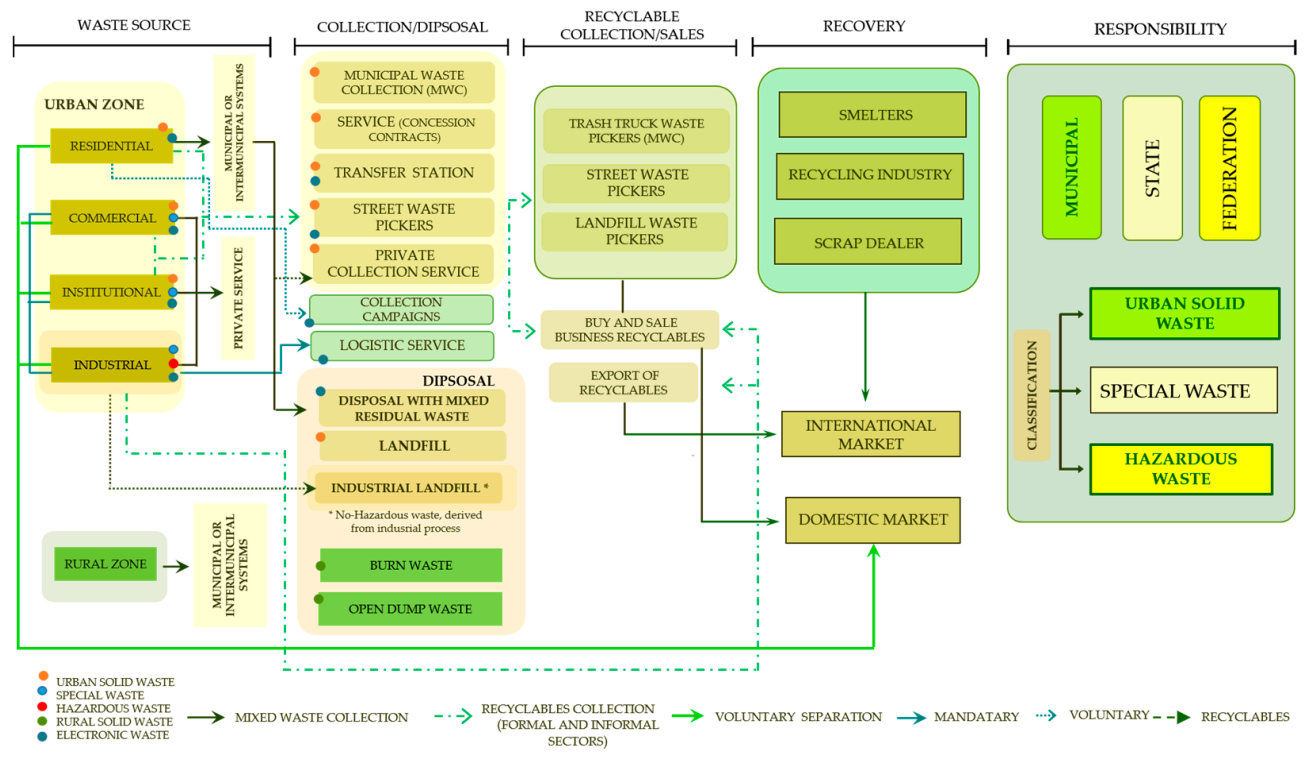

Figure 3. Waste system in Mexico.

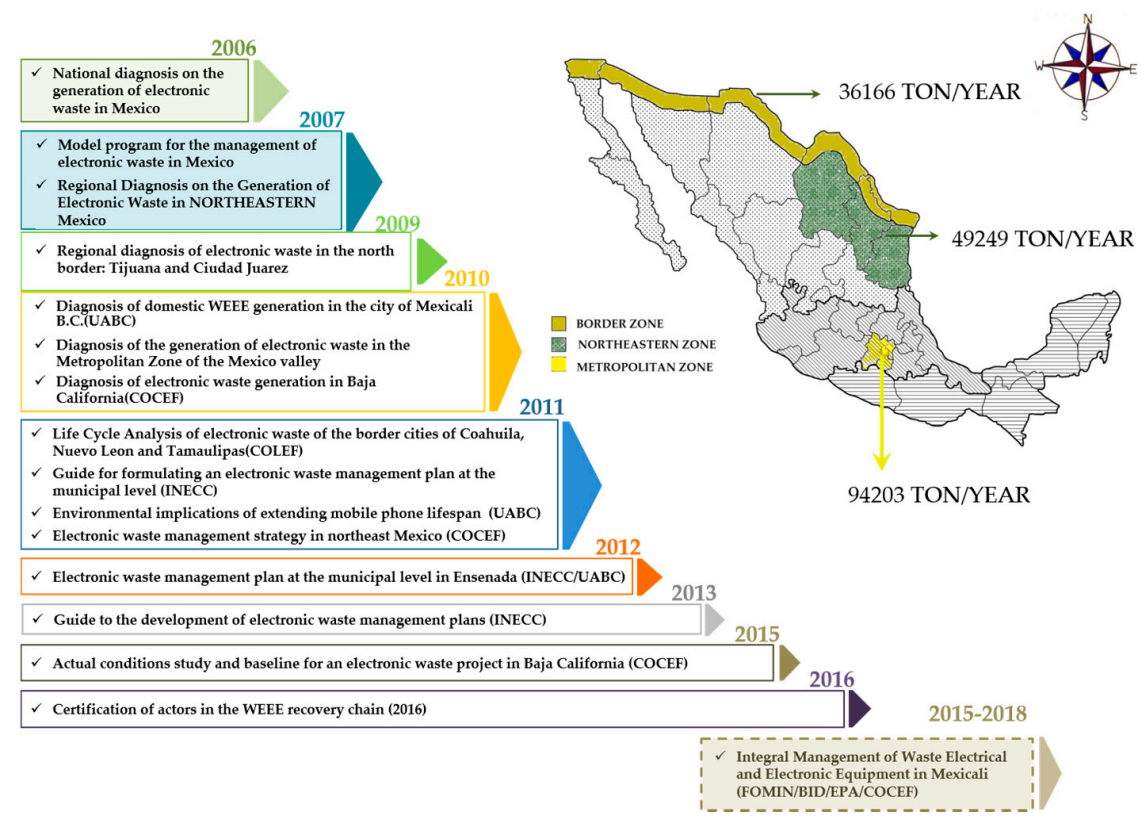

Figure 4. Evolution of the studies about electronic waste in Mexico. Source. Own construction.

It has been evaluated in the different "diagnoses of WEEE" at regional and national levels [17-24] that the percentage of waste collected through government programs and private enterprises is $10 \%$ of the WEEE generated. On the other hand, in the study carried out by Alcántara-Concepción et al. [25], 
they found that 7\% of WEEE is collected through the System for Municipal Solid Waste and transferred to the recycling companies.

Expectations for growth in WEEE collection and recycling will depend on incentives and regulations in the country, but there is no encouraging scenario because the only WEEE standard in the country [26] is that companies that manage and/or generate WEEE realize a registry for each district of the Mexican Republic with the corresponding "management plan", but the response to this new legislation has not had the desired effects, with low influence in the registry offices, and even the government response by district has been slow.

As mentioned above, $10 \%$ of WEEE is collected by government collection programs and private companies, while $7 \%$ of WEEE that is transferred through the informal sector inserted into the municipal solid waste collection system for its recycling.

Figure 5 presents a projection of the electronic waste generation from 2006 to 2018 and, according to generation data, growth in 2016 was 50\% higher than that recorded in 2006.

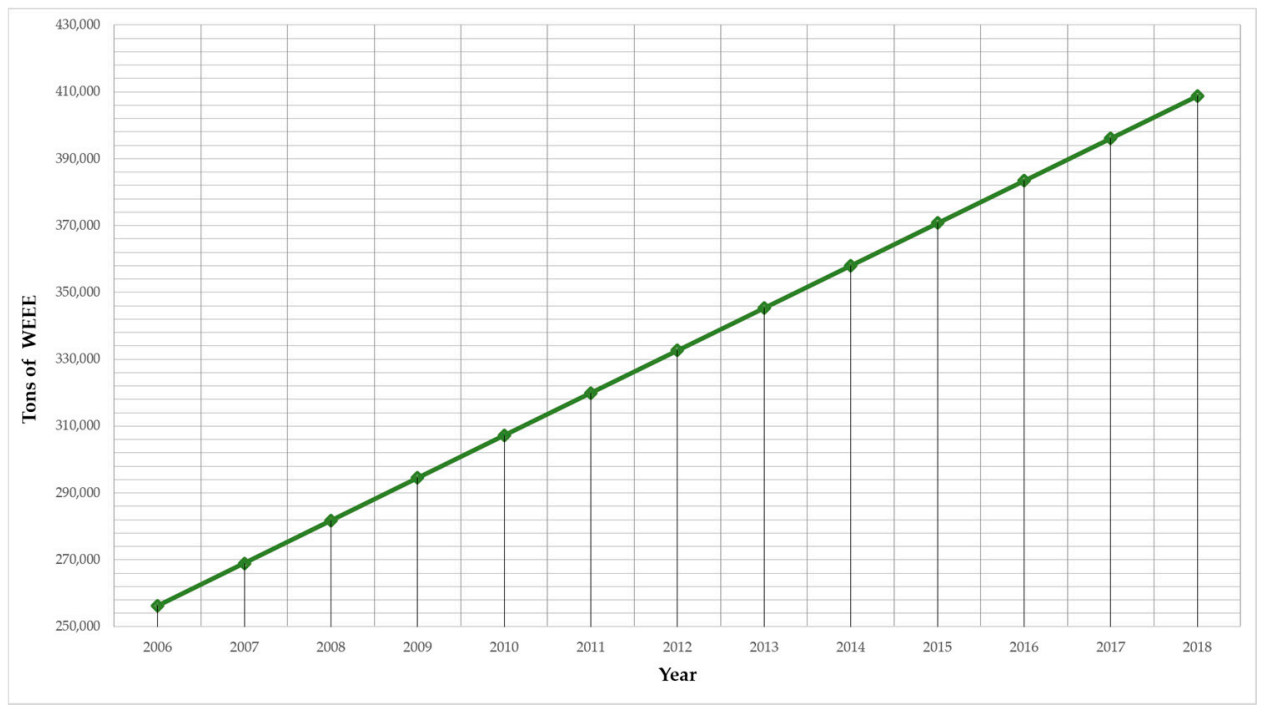

Figure 5. Electronic waste generation in Mexico.

Table 1 shows examples of the materials included in some electrical and electronic equipment. The table was elaborated from National Institute of Ecology and Climate Change (INECC by its acronym in Spanish) studies [19-24] and with interviews and field visits to 27 recycling e-waste companies in Mexico [25].

Table 1. Amounts of materials in some electrical and electronic equipment in Mexico (kg/ton recycled).

\begin{tabular}{|c|c|c|c|c|c|c|c|}
\hline & \multirow{2}{*}{ Composition } & \multirow{2}{*}{$\begin{array}{l}\text { Refrigerators } \\
(23 \mathrm{ft}) \text { and } \\
\text { Heating }\end{array}$} & \multicolumn{2}{|c|}{ Equipment } & \multicolumn{2}{|c|}{$\begin{array}{c}\text { TV and } \\
\text { Monitors }\left(35^{\prime}\right)\end{array}$} & \multirow{2}{*}{$\begin{array}{l}\text { Lighting } \\
\text { Equipment }\end{array}$} \\
\hline & & & $\begin{array}{c}\text { Large } \\
\text { Household } \\
\text { Appliances }^{3}\end{array}$ & $\begin{array}{c}\text { Small } \\
\text { Household } \\
\text { Appliances }\end{array}$ & CRTs & FPDs & \\
\hline & Polystyrene & 7.4 & 8.5 & - & - & - & - \\
\hline & $\begin{array}{c}\text { Acrylonitrile } \\
\text { butadiene styrene }\end{array}$ & - & - & - & 8.5 & 1.3 & - \\
\hline \multirow{5}{*}{$\begin{array}{l}\text { Metals and } \\
\text { Rare Earths }\end{array}$} & Aluminum & 1.7 & 7.1 & 1.6 & 1.5 & 1.1 & 3.5 \\
\hline & Cobalt & - & - & 0.08 & - & - & - \\
\hline & Commercial frit ${ }^{1}$ & - & - & - & 0.4 & 4.0 & 750 \\
\hline & Cooper & 1.2 & 0.9 & 3 & 2.9 & 2.8 & - \\
\hline & Gold & - & 0.00015 & 0.005 & 0.02 & 0.02 & - \\
\hline
\end{tabular}


Table 1. Cont.

\begin{tabular}{|c|c|c|c|c|c|c|c|}
\hline & \multirow[b]{2}{*}{ Composition } & \multirow{2}{*}{$\begin{array}{c}\text { Refrigerators } \\
(23 \mathrm{ft}) \text { and } \\
\text { Heating }\end{array}$} & \multicolumn{2}{|c|}{ Equipment } & \multicolumn{2}{|c|}{$\begin{array}{c}\text { TV and } \\
\text { Monitors }\left(35^{\prime}\right)\end{array}$} & \multirow{2}{*}{$\begin{array}{l}\text { Lighting } \\
\text { Equipment }\end{array}$} \\
\hline & & & $\begin{array}{c}\text { Large } \\
\text { Household } \\
\text { Appliances }{ }^{3}\end{array}$ & $\begin{array}{c}\text { Small } \\
\text { Household } \\
\text { Appliances }\end{array}$ & CRTs & FPDs & \\
\hline \multirow{5}{*}{$\begin{array}{l}\text { Metals and } \\
\text { Rare Earths }\end{array}$} & Manganese dioxide & - & - & 0.009 & - & - & - \\
\hline & Nickel & - & 0.022 & 1.04 & 3.11 & 2.77 & - \\
\hline & Palladium & - & 0.00022 & 0.01 & 0.03 & 0.03 & - \\
\hline & Silver & 0.004 & 0.18 & 0.18 & 0.53 & 0.48 & - \\
\hline & Steel & 4.71 & 6.65 & 490 & 97 & 380 & \\
\hline \multirow{2}{*}{$\begin{array}{c}\text { Other } \\
\text { Materials }\end{array}$} & $\begin{array}{c}\text { Plywood } \\
\text { (diameter: } 0.0096 \mathrm{~m}^{3} \text { ) }\end{array}$ & - & 0.0005 & 0.0005 & 0.009 & - & - \\
\hline & Chromium steel $^{2}$ & - & 5.5 & - & - & - & - \\
\hline
\end{tabular}

The WEEE contain heavy metals such as lead $(\mathrm{Pb})$, cadmium $(\mathrm{Cd})$, chromium $(\mathrm{Cr})$, manganese $(\mathrm{Mn})$, nickel $(\mathrm{Ni})$, mercury $(\mathrm{Hg})$, arsenic $(\mathrm{As})$, copper $(\mathrm{Cu})$, zinc $(\mathrm{Zn})$, aluminum $(\mathrm{Al})$ and cobalt $(\mathrm{Co})[27,28]$ and organic pollutants, including polycyclic aromatic hydrocarbons (PAHs), polychlorinated biphenyls (PCBs), brominated flame retardants (BFRs), such as polybrominated diphenyl ethers (PBDEs), or other compounds such as polychlorinated dibenzo-p-dioxin/furans (PCDD/Fs) [29], which can be released from artisanal thermal recycling processes or inadequate recycling processes of WEEE [30], and subsequently have been found in different environmental matrices with adverse negative environmental effects [31,32].

\section{Instruments and Regulation of Electronic Waste Management in Mexico}

Electronic waste regulation is still in its initial stages in Mexico. To date there is neither a specific law nor regulation about electronic waste management. There are legal frameworks that deal with WEEE and several other instruments and regulations that will be described below (Figure 6).
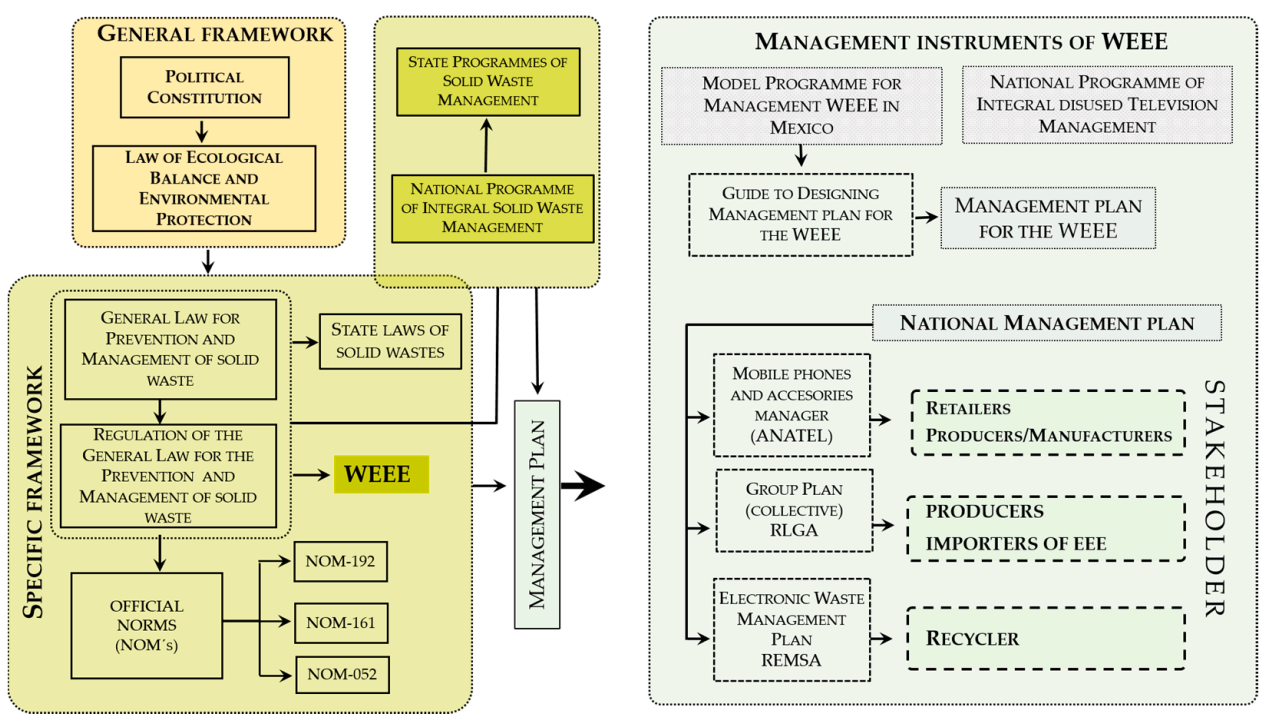

Figure 6. Instruments and regulation for e-waste management.

The legal framework of waste management is based on the Mexican Political Constitution, particularly article 115, which states that municipalities are responsible for providing public cleaning services, as well as being in charge of collecting, transporting, treating, and final disposal of waste. 
The main environmental law that regulates hazardous waste is the General Law of Ecological Balance and Environmental Protection (LEGEEPA by its acronym in Spanish). LEGEEPA states specific guidelines for waste disposal and the accountability for waste management at the three levels of government. In 2003, the General Law for Waste Prevention and Integrated Management (LGPGIR by its acronym in Spanish) was enacted. LGPGIR is a specific regulatory framework for solid waste that defines a classification and three main categories of waste, such as hazardous waste, special handling waste, and urban solid waste [33]. According to the LGPGIR, WEEE is included under special handling waste. LGPGIR defines WEEE as "technological waste from software industries, electronic product manufacturers and others that, once past their useful life, requires specific handling". Article 9 of the LGPGIR establishes the authority of the governments of districts to authorize the integral management of waste that needs special management, and to identify those within their territory that may be subject to management plans. Furthermore, as of the year 2013, the NOM-161-SEMARNAT-2011 [26], a standard that defines WEEE as special management waste, should be taken into account in the management plans of government structures and private institutions. However, depending on the source that generates it, and its composition, it can be urban waste, require special handling, and/or it can hazardous, which makes the handling of the waste stream in Mexico more complex [34].

Regulation of the General Law for the Prevention and Management of Solid Waste (RGPGIRS by its acronym in Spanish) defines the instrumentation plans for special handling of waste that represents an environmental risk and seeks to encourage material valorization. It also indicates that classifying waste for special handling, in terms of LGPGIR, will be established according to the Mexican Official Regulation (NOM by its acronym in Spanish); this regulation promotes the management plan of priority streams of waste, such as electronic waste [35]. NOM-052-SEMARNAT-2005 includes several electronic products as hazardous waste, along with their characteristics, identification procedure, classification, and components. It is argued that those electronic products are included on the list because they have substances that are corrosive, highly reactive, flammable, or toxic [36].

Additionally, the NOM-161-SEMARNAT-2011 sets criteria for including electronic waste products in the special waste classification and determines which ones should have a management plan and how to set up such a management plan. This regulation catalogues the products that, once past their useful life, must be included in a management plan. Those products are: technological waste produced in the software and electronic product industries, computer desktop devices and their accessories, computer laptops and their accessories, cellular phones, cathode-ray tube monitors (including televisions), LCD monitors and plasma (including televisions), portable audio and video players, printers and electronic equipment cables, and copiers and multifunctional devices [26].

It is the goal of WEEE management plans to minimize generation and maximize waste valorization. Management plans should have specific actions to improve environmental, technological, economic, and social efficiency. Management plans should be designed to set accountability and integral handling as well. They must consider all actions, procedures, and viable means that involve manufacturers, importers, exporters, distributors, dealers, consumers, sub-product users, and large generators of waste as appropriate, as well as all three levels of government.

Handling WEEE is complex because of its wide variety of products. Additionally, there is a large diversity of compositions and components, made of different materials, as well as many hazardous substances. That variety of products, compositions, components, and materials is especially difficult during the handling phase. In particular, electronic waste products that include substances such as heavy metals are the most challenging in terms of management. Among the heavy metals included in WEEE we can find mercury, lead, cadmium, and chromium, halogenated substances, such as chlorofluorocarbons (CFCs), chlorinated biphenyls (PCBs), and polyvinyl chloride (PVC), as well as some flame retardants. Therefore, it is important to evaluate the risks and make integral e-waste management strategies [37,38]. 


\section{Actors in the Chain of WEEE Recovery in Mexico}

Considering the activities conducted by each actor when handling e-waste, there are four groups of actors: producers, generators, managers, and recyclers. According to the life cycle of WEEE, the value chain starts with the definition of the market. The life cycle goes from a new EEE or used (EEEU) product to the final disposal of the product as waste. Both types of sectors, formal and informal, are part of the life cycle (Figure 7). The EEE producer is usually a legal person certified as an EEE or EEEU manufacturer, assembler, importer, distributor, or dealer. A manager is defined as any legal person that provides a collection of EEE- or EEEU-related services, transportation, and storage, even if they do so for only a portion of the process. A recycler is any legal person that adds some WEEE treatment and/or transformation, conducting an effective segregation of their components.

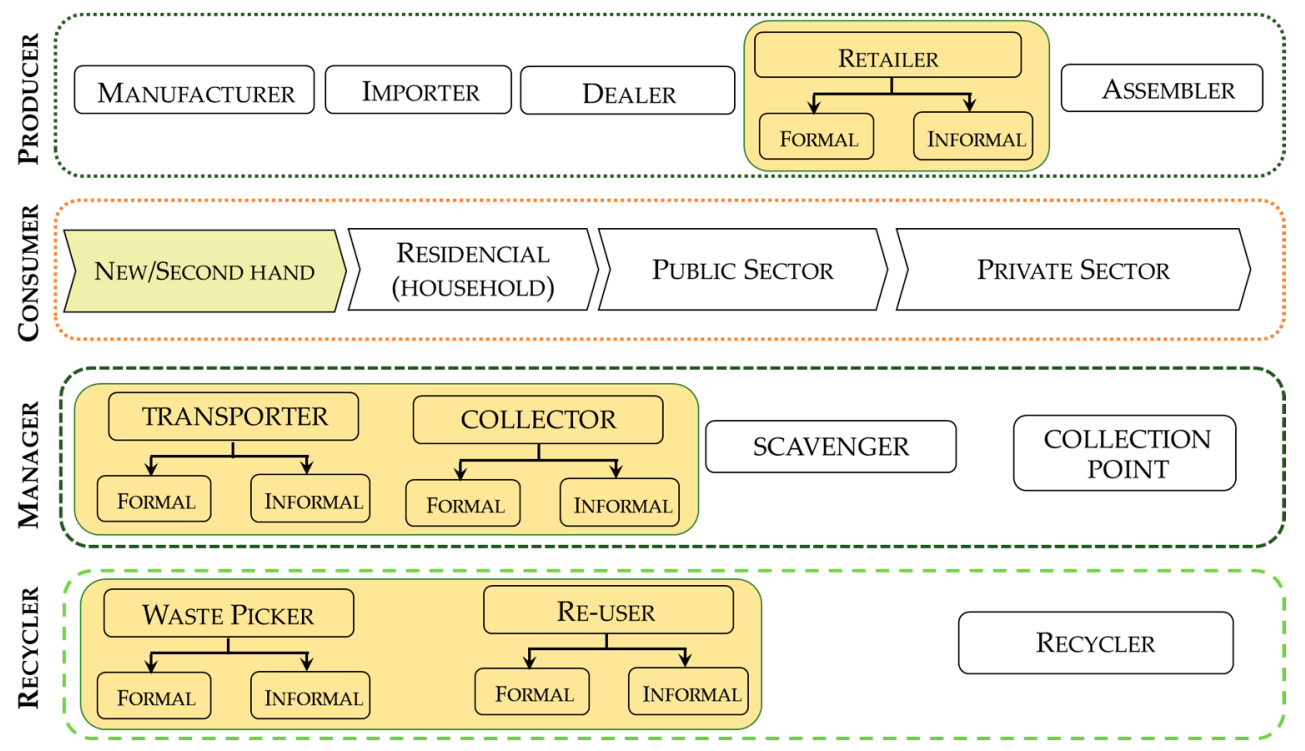

Figure 7. Electronic waste handling in Mexico.

In order to identify all actors involved in the value chain of the recovery of WEEE, we built an EEE life cycle model. Our EEE life cycle model identifies the flux of materials from their production to their final disposal. Our model is relevant to any WEEE management plan because it sets how WEEE changes across its life cycle, stating the links where each actor processes the WEEE with the purpose of recovering useful materials, identifying the components of the system and the relations that connect the four different life cycle stages of any EEE (Figure 8). By identifying each stage, it is possible to state the flux of materials, including material inputs and outputs, as well as making it possible to quantify WEEE generation and recovery volumes.

There are a large number of recovery practices conducted by different actors. Such practices aim to segregate, repair, recondition, and/or commercialize disused equipment. Involved actors see recovery practices as an opportunity to gain economic benefits. Those actors cover the social need of managing this kind of waste as well. The actors in the Mexican case include both formal and informal sectors.

Regarding the formal sector, there are governmental management instruments to deal with WEEE. All involved actors must state management plans, or be added to an already registered management plan, to conduct WEEE recovery and management. Management plans should state and declare WEEE generation points, their flux, and their outputs.

Regarding the informal sector, WEEE management is focused on any component or material that has a value and/or can be commercialized. This management is usually done at illegal sites and when selecting WEEE from urban waste. 
The mechanism that has been implemented for WEEE generation in the residential sector is to promote direct collection campaigns, mainly conducted by WEEE recycling industries allied with local governments, schools, and/or non-governmental organizations (NGOs). Those campaigns usually allow for massive e-waste collection by making an effective, environmentally adequate, and safe storage collection center.

Figure 9 provides a general scheme of the actors and involved processes when handling WEEE. It also makes evident that the final waste destination is split between both formal and informal sectors.

WEEE recovery is fundamental for optimizing the re-utilization of raw materials; additionally, it avoids environmental and energetic impacts because recovery is made through traditional methods. For this reason, the recycling of WEEE is an important topic not just from the point of view of waste treatment, but also from a material recovery perspective.

In Mexico, full WEEE recycling processes are relatively new. Currently, the amount of recovered materials is very small, and the political framework and infrastructure are still limited. Thus, the actual industry cannot process large amounts of WEEE. Most of the WEEE recycling companies do not offer the full recovery cycle because they are focused only on the recovery of valuable components, leaving non-valuable components aside. Those non-valuable components are still a problem because they have no current economic value, but represent health and environmental risks. An example of valuable components is printed circuit boards, and an example of a non-valuable component is a cathode ray tube (CRT).

The recycling market of electronic products in Mexico is made mainly of three groups: small and medium businesses exclusively dedicated to the recovery and revaluation of materials from collection programs or equipment tax breaks, and scrap dealers, and waste pickers or locals dedicated to carrying out valuable components recovery, such as that of cables and printed circuit boards.

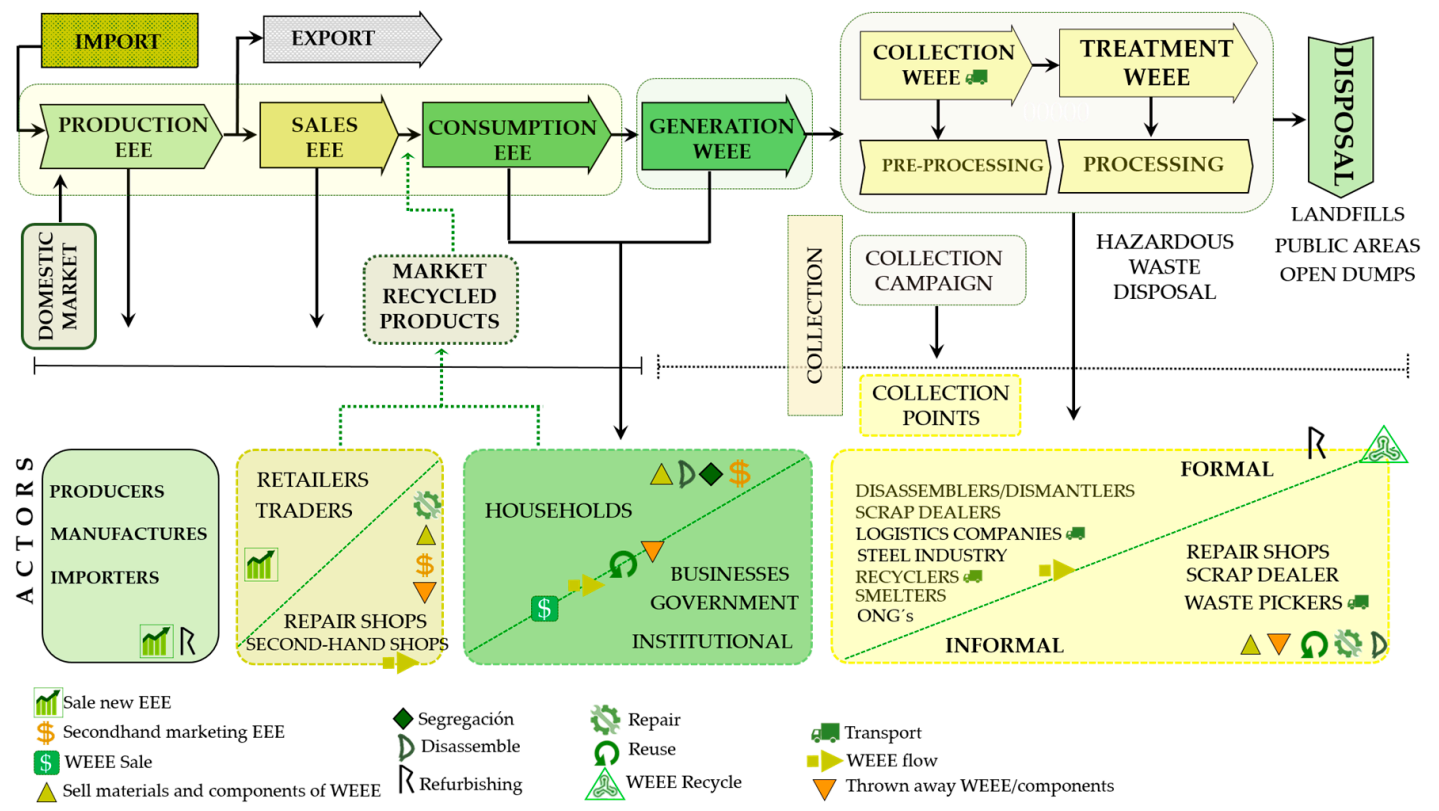

Figure 8. Actors and processes in electronic waste recovery in Mexico. 


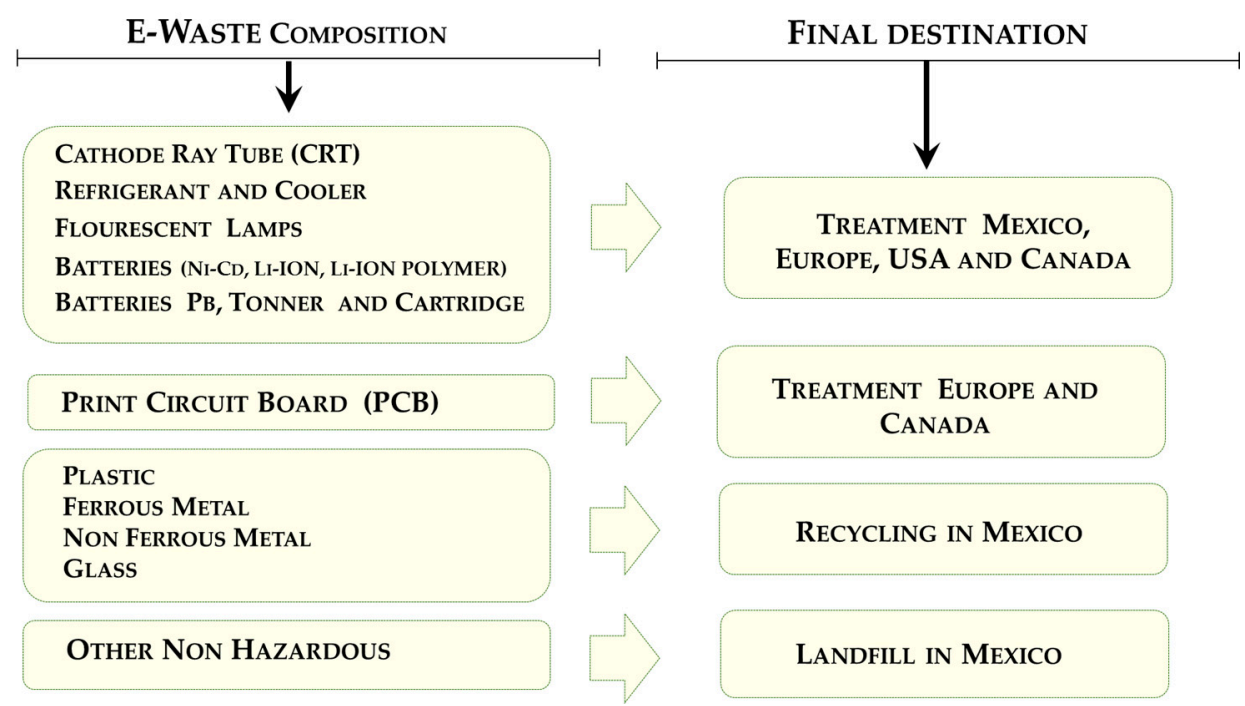

Figure 9. Electronic flow sent for treatment in the formal sector. Source. Prepared by the authors based in [39].

The recycling of WEEE is a source of employment and income for the informal sector made by intermediaries and recyclers that work in the streets, or in small workshops, disposition sites, and their own homes [40].

The processes performed by different actors, both formal and informal, in the value chain are collecting, manual dismantling, reconditioning, and recycling, mainly recovering plastics, metals, cables, and printed circuit boards contained in WEEEs that are finally transformed into secondary resources for production chains. The unusable, frequently hazardous components are discharged and thrown away or left on sidewalks or in wastelands, and illegal landfills.

Figure 10 shows the differences between the formal and informal channels for WEEE management in Mexico.

\section{INFORMAL SECTOR}

Collection of equipment by waste pickers or Deliver by consumer

Manual separation and dismantling

Repair

Reuse equipment or component

Burned e-waste from recover valuable

Primitive recycling procedures

Sale recycles to middleman

Throw in the trash hazardous waste
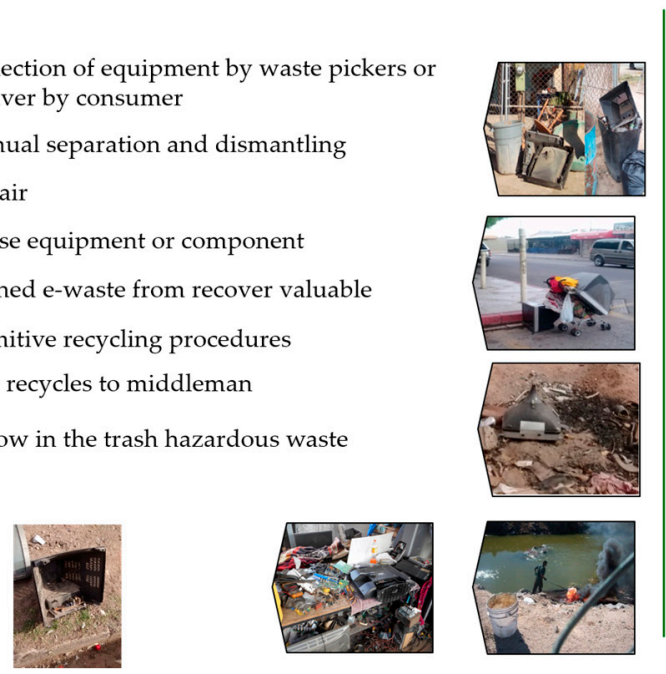

FORMAL SECTOR

Collection of equipment by

collection campaign, clean point,

logistic service, collection service.

Delivery to qualified waste managers

Mechanical separation and dismantling

Pretreatment

Recycling facilities

Sale recycles domestic markets and export

Disposal of non-recyclable in Landfill

Disposal hazardous waste
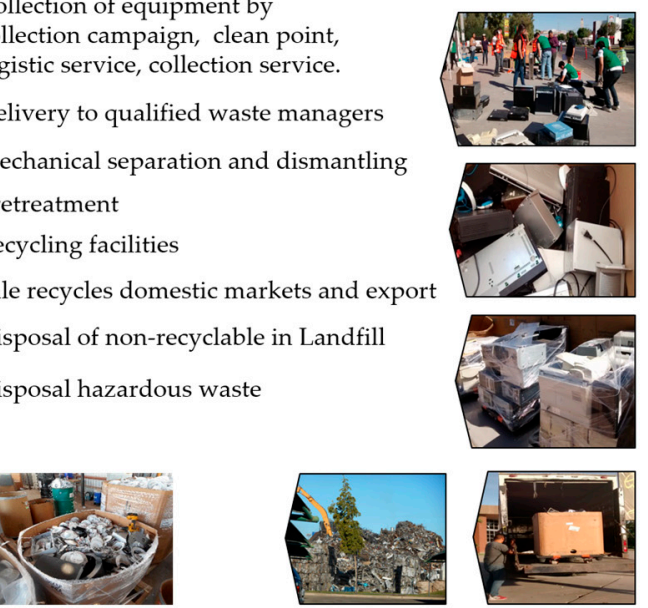

Figure 10. Differences between formal and informal channels for e-waste management in Mexico. 


\section{Sustainable Model for WEEE Recovery in Mexico}

Mexico, just like the rest of the developing world, faces the challenge of having effective strategies to cover all EEE life cycle phases. This need is especially urgent in the obsolescence phase. Some of the main problems at the obsolescence phase are: (1) a lack of infrastructure, especially during the WEEE pre-process and treatment; (2) the absence of facilities and technologies of innovation; (3) the lack of investment; (4) high management costs; and (5) social and security problems.

A principle to be incorporated into the recovery stage of WEEE is the recovery of functional equipment in disuse, which applies the Swiss model [41,42]. Companies specialize in the maintenance and upgrading or the functional refurbishment of EEE in disuse that still functions, which subtracts or receives equipment from the market, and changes or incorporates new devices to extend their useful life. There are also multinational companies that remanufacture or provide technical services, and NGOs promoting the reuse and refurbishment of EEE.

Health is one of the problems associated with recovery activities in countries such as Mexico. The main reason is that a large share of the recycling activities are covered by the informal sector. The informal sector reconditions and selects materials from EEE using people (from technicians to waste pickers) that do not use appropriate equipment and have little or no knowledge about potentially hazardous elements. This lack of knowledge and equipment leads to the exposure of not only informal WEEE-related workers but also the general public to health problems. This is a threat as the impacts caused by WEEE can increase exponentially when accumulation and synergistic interactions occur. We believe that the Swiss model for recycling EEE can help in dealing with these issues since that model proposes three recycling principles: functional recovery, material, and energy. Developing formal companies that manage WEEE prior to reaching the informal sector makes it possible to avoid environmental and health issues while maximizing the return from disused electronic equipment (Figure 11).

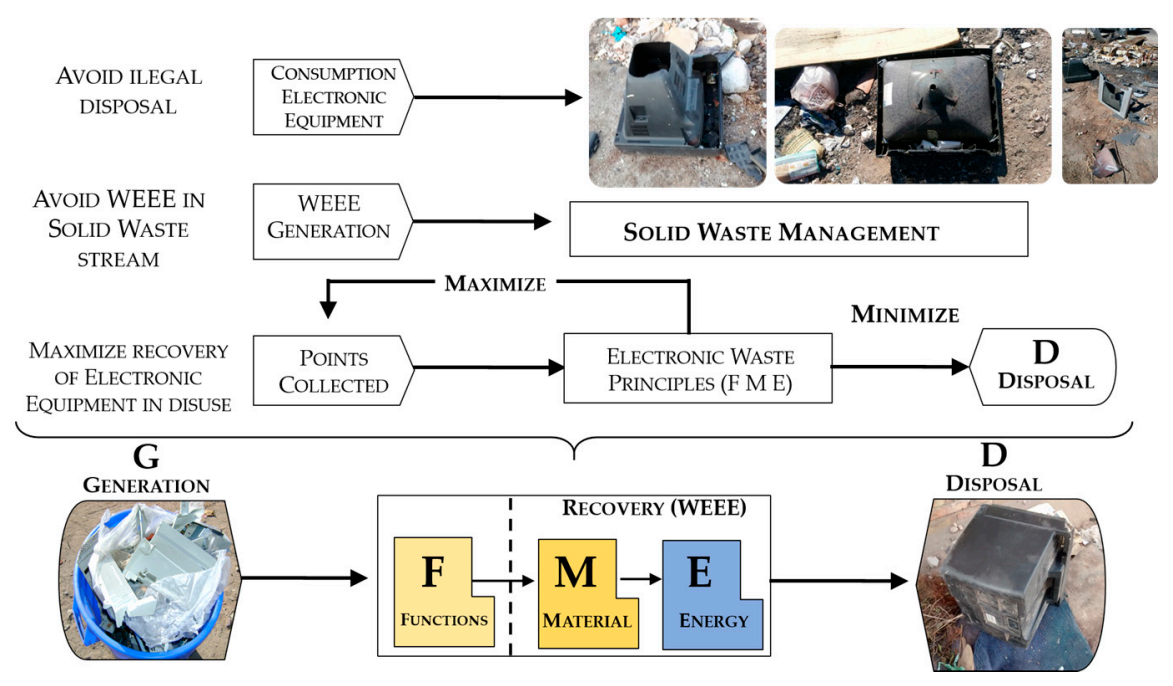

Figure 11. Disuse electric and electronic equipment recovery principles. Source: Prepared by authors based on [41].

As a national policy in WEEE management, a handling plan is proposed, which is an instrument that can promote the minimization of generation and can maximize the recovery of electronic waste. This can be the starting point for a sustainable model proposal of WEEE management, considering that WEEE handling includes the entire chain of processes and treatments that must be met with respect to the existing regulations.

Figure 12 shows a diagram that establishes the basic elements that must be considered when formulating an electronic waste system that promotes sustainable waste management. 


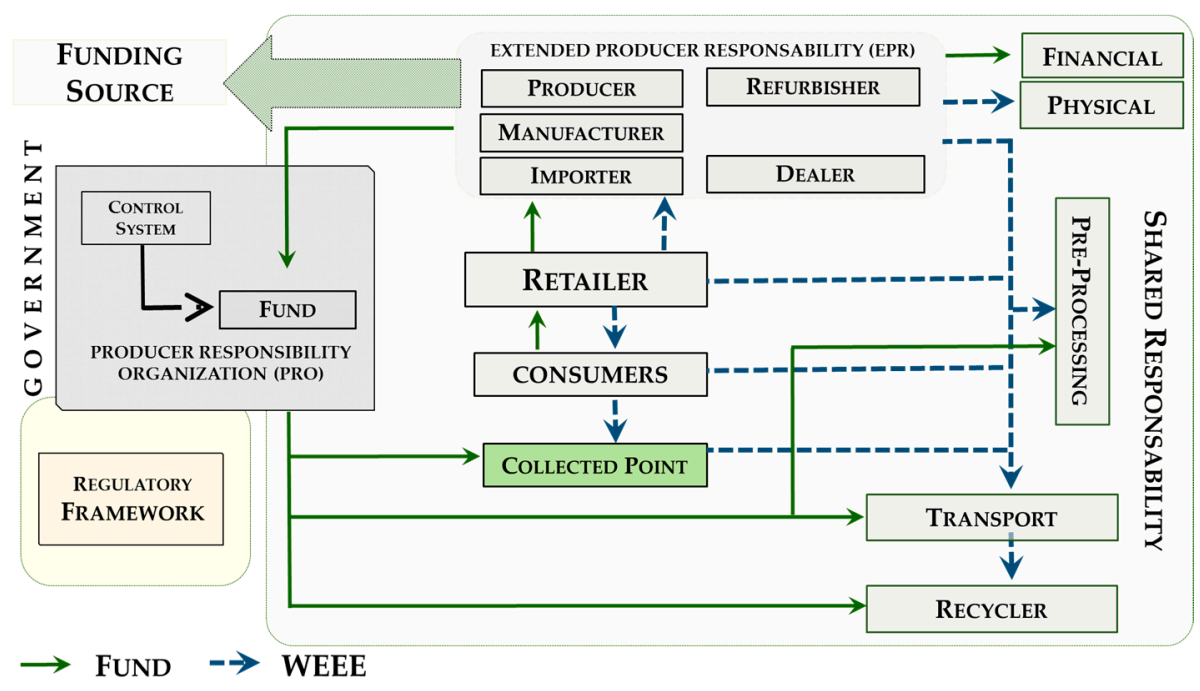

Figure 12. Diagram for a sustainable WEEE management plan.

The sustainable management of WEEE requires that a financing system be established so it can operate, in which the actors involved can participate. It is important that users know how and where to deliver obsolete equipment. For that, a collecting system must be implemented where users have easy access, including a delivery system for products at the end of their useful life. It is also important to promote the system for users' sensitization. For the functioning of the system, it is important to establish collecting sites; these might meet certain basic standards of environmental protection, and may have sufficient space for the storage of equipment for a specific period of time.

In a WEEE management system, the handling plan is an instrument to promote rational and consistent waste management, opening an opportunity to obtain some materials, as well as to dispose at sites designed to receive waste that is not recoverable, but which can confine hazardous materials according to regulations.

Electronic waste is not something to be abandoned or discharged, but rather a valuable resource, for which it is necessary promote sustainable practices with which, when applying an adequate combination of policies, the WEEE management can offer economic, social, and environmental benefits; the first one is obtained by introducing efficient practices of production and consumption permitting not only the recovery of valuable material, but also employment generation and the advantages of business opportunities. The second benefit is present when communities work in the informal recovery of WEEE, getting out of severe poverty, and reducing or solving health problems. The last benefit is obtained when impacts are reduced or eliminated so that air and water quality are improved and when greenhouse gas emissions are reduced, among others.

A sustainable management of electronic waste depends on a feasible financing system which, ideally, includes collecting phases, transport, treatment, and disposal [43]. Here, we present a model to set the financing system (Figure 13). We propose a fund creation based on a returning tax policy over each recycled WEEE. A control system ought to be set in order to assure resource transparency. The system should work by sharing accountabilities and function under a specific regulation framework for electronic waste management. Our suggestion is to include an extended producer responsibility (EPR) program. The EPR will make each producer accountable for the entire lifecycle of each EEE product they produce. Special attention should be given to the post-consumption phase (that includes collecting, recovery, and final disposal). An EPR has to be implemented across all WEEE management instruments. 


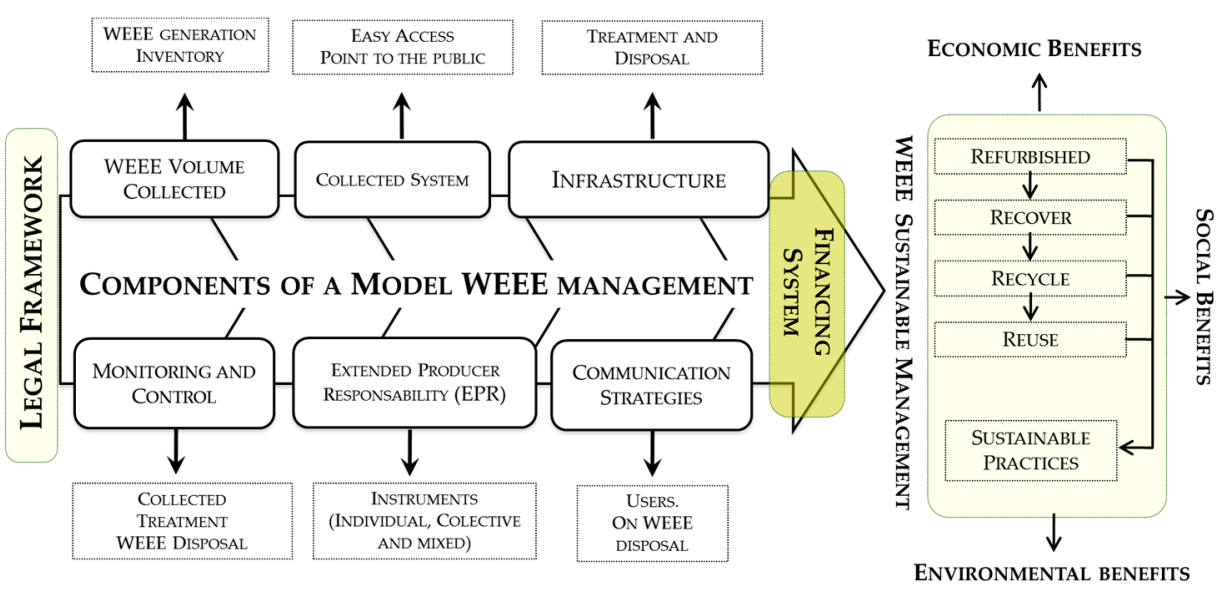

Figure 13. Components of a sustainable management model of electrical and electronic waste.

There is a set of economic instruments that varies across each EEE phase. Some of these instruments are taxes, deposit refunds, and subsidies. The combination of these instruments will determine how to apply a specific EPR (individually, collectively, or a combination of both). Even with a mandatory EPR program, we are making each producer accountable for their products, though it does not mean that each producer must assume all responsibility for managing their own products through the end of their useful life.

Different industries and NGOs will be able to gather in an organization of responsibility of producers (ORP). Each ORP can coordinate efforts, fund management participation, and ensure the completion of the post-consumption management phase [44].

\section{Challenges and Opportunities}

\subsection{Challenges}

Electrical and electronic waste equipment management is an important challenge for countries such as Mexico. Among the challenges for this country is obtaining a precise estimation of WEEE volume, since part of this waste stream is difficult to calculate, because a proportion of electronic equipment that has been commercialized goes to the internal market without being registered. In other countries, this is called "invisible entry" [45]. Information generation related to the special handling of waste generation among electronic waste is an activity that must be developed, and which helps to establish public policies oriented toward WEEE management.

Authorities face the challenge of overcoming some barriers that are identified in the implementation stage of the management plans of WEEE at the national level; among these are the criteria of homologation by different federative entities with respect to permit issue, transport procedures, and collecting, which industries must meet in order to avoid inefficiencies and disparities that coexist in the management of this waste, and they also require reinforcing the regulation framework to make handling plan presentations mandatory, clearly defining the persons who are forced to present, as well as defining, precisely, the roles and responsibilities of the actors involved, the interest groups, and their responsibilities.

Another important challenge is modifying the practice of mixed WEEE disposal with the urban waste stream, which means working with actors of the recovery chain belonging to the informal sector and with generators at the residential level. It is necessary that the implementation of a management system applies the principle of shared responsibility that is established in waste law. 


\subsection{Opportunities}

There is already a social consensus among the general public, NGOs, and producers that the generation of WEEE is becoming a health and environmental problem. Many NGOs, educational institutions, and businesses are currently implementing campaigns and strategies to collect WEEE and are actively looking to return it to the recovery chain. Through enhancing and consolidating this consensus is a great opportunity to make a sustainable WEEE management possible.

There are already several WEEE commercialization markets. There is an opportunity to take advantage of those markets by setting training and monitoring practices over single actors. If we set those practices, it will be possible to manage WEEE in a sustainable way that includes capital gains from new recovery material processing. It will also be possible to set adequate WEEE disposal sites and to be environmentally friendly. The current recovery chain is already yielding social and environmental benefits.

An integral and sustainable WEEE management plan/model taking account of both challenges and opportunities is mandatory if we want to avoid environmental damage that would impose major costs for us and future generations.

\section{Conclusions}

Production and consumption practices should be revamped in a sustainable way. WEEE is not something to abandon or discharge elsewhere, but a valuable resource. We have to promote sustainable practices that, when applied in combination with adequate policies, allow economic, social, and environmental benefits. Among the benefits it is clear that new, safe, and stable employment will be generated, but also that there will be advantages of new business opportunities. Furthermore, a sustainable WEEE management plan will provide a means to reduce poverty and health problems, as well as reduce environmental impacts.

Mexico still has a long way to go to achieve sustainable WEEE management. Requirements include increasing local awareness, conducting a permanent recycling campaign among businesses and schools, and developing federal and local efforts that, ultimately, lead to cultural changes regarding our use and management of WEEE. Along with the awareness activities, Mexico needs to set changes in legislation and set effective instruments that deal with current pitfalls. It needs to create more accountability for EEE producers, authorities, WEEE companies, and the public as well.

Finally it is essential that Mexico establishes integral management programs for WEEE starting from the federal level through to municipalities, in which the promotion of a management model with private participation can be adaptable to the municipality, with the objective of the sustainable management promotion of WEEE. Within this management process, collection, recondition, repair, reuse, and final disposal must involve all actors that participate in the value chain, among which are producers, marketers, customers, transporters, collecters, repairers, and recyclers. There must be a formal return system, the establishment of a finance system, separation programs at the source, the promotion of infrastructure installation, and access to technologies and investement for treatment of WEEE.

Given that other countries do have similar WEEE problems, especially in regard to the lack of infraestructure and the high levels of informal markets, it is possible to implement the model proposed in this manuscript in other countries. In our model, we focused on the different life cycle phases and their relatioships, the involved actors, and the residual value chain. Furthermore, the model reenacts the functions performed by the involved teams by valuing each practice, preventing the WEEE from getting into the urban waste cycle and making null the irregular disposal, as well as maximizing obsolete electronic equipment returns. Uncertainty is an element to be considered when analyzing WEEE management systems. Therefore, we recommend applying uncertainty methods in future WEEE recycling research and methods. The inclusion of uncertainty methods will ease decision-making. Some of these methods include fuzzy logic, neural networks, and a suit of statistical tools such as stochastic programming, inverse uncertainty quantification, and multicriteria analysis, among others. 
Acknowledgments: The authors wish to acknowledge the Border Environment Cooperation Commission (COCEF), the financing granted to carry out the project TAA15-026 "Actual conditions study and baseline for a project of electronic waste".

Author Contributions: Samantha E. Cruz-Sotelo, Sara Ojeda-Benitez, and Karla I. Velázquez-Victorica wrote the paper. All of the authors contributed to analyzing the actors participating in the recovery chain and model definition. Néstor Santillán-Soto and O. Rafael García-Cueto analyzed management instruments and regulations, Jorge Jáuregui-Sesma, Victor Alcántara Concepción, and Camilo Alcántara provided technical and logistical support in the field and analyzed actors in the chain of WEEE in Mexico, and contributed to writing the manuscript.

Conflicts of Interest: The authors declare no conflict of interest.

\section{References}

1. Cucchiella, F.; D'Adamo, I.; Koh, S.L.; Rosa, P. Recycling of WEEEs: An economic assessment of present and future e-waste streams. Renew. Sustain. Energy Rev. 2015, 51, 263-272. [CrossRef]

2. Wang, S.; Li, W.D.; Xia, K. Customized disassembly and processing of waste electrical and electronic equipment. Manuf. Lett. 2016, 9, 7-10. [CrossRef]

3. Kim, M.; Jang, Y.C.; Lee, S. Application of Delphi-AHP methods to select the priorities of WEEE for recycling in a waste management decision-making tool. J. Environ. Manag. 2013, 128, 941-948. [CrossRef] [PubMed]

4. Tan, M.J.; Owh, C.; Chee, P.L.; Kyaw, A.K.K.; Kai, D.; Loh, X.J. Biodegradable electronics: Cornerstone for sustainable electronics and transient applications. J. Mater. Chem. C 2016, 4, 5531-5558. [CrossRef]

5. Kang, H.Y.; Schoenung, J.M. Electronic waste recycling: A review of U.S. infrastructure and technology options. Resour. Conserv. Recycl. 2005, 45, 368-400. [CrossRef]

6. Vega, O.A. Efectos colaterales de la obsolescencia tecnológica. Revista Facultad de Ingeniería UPTC 2012, 21, 55-62.

7. Amankwah-Amoah, J. Integrated vs. add-on: A multidimensional conceptualisation of technology obsolescence. Technol. Forecast Soc. Chang. 2016, in press.

8. Araújo, M.G.; Magrini, A.; Mahler, C.F.; Bilitewski, B. A model for estimation of potential generation of waste electrical and electronic equipment in Brazil. Waste Manag. 2012, 32, 335-342. [CrossRef] [PubMed]

9. Georgiadis, P.; Besiou, M. Environmental strategies for electrical and electronic equipment supply chains: Which to choose? Sustainability 2009, 1, 722-733. [CrossRef]

10. Baldé, C.P.; Wang, F.; Kuehr, R.; Huisman, J. The Global E-Waste Monitor 2014; IAS-SCYCLE; United Nations University: Bonn, Germany, 2015; p. 74.

11. Heacock, M.; Kelly, C.B.; Asante, K.A.; Birnbaum, L.S.; Bergman, Å.L.; Bruné, M.N.; Kamel, M. E-Waste and Harm to Vulnerable Populations: A Growing Global Problem. Environ. Health Perspect. 2016, 124, 550-555. [CrossRef] [PubMed]

12. United Nations University. StEP Launches Interactive World E-Waste Map. Available online: http:/ / unu.edu/media-relations/releases/step-launches-interactive-world-e-waste-map.html\#info (accessed on 21 June 2016).

13. García, A.C. ¿Avances en la prevención y reducción de residuos de aparatos eléctricos y electrónicos? Revista CESCO de Derecho de Consumo 2015, 13, 214-222.

14. Mmereki, D.; Li, B.; Li'ao, W. Waste electrical and electronic equipment management in Botswana: Prospects and challenges. J. Air Waste Manag. Assoc. 2015, 65, 11-26. [CrossRef] [PubMed]

15. Cyranek, G.; Silva, U. Los Residuos Electrónicos: Un Desafío para la Sociedad del Conocimiento en América Latina y el Caribe; Plataforma RELAC SUR/IDRC; UNESCO: Montevideo, Uruguay, 2010; p. 259.

16. Khan, S.A. E-products, E-waste and the Basel Convention: Regulatory Challenges and Impossibilities of International Environmental Law. Rev. Eur. Comp. Int. Environ. Law 2016, 25, 248-260. [CrossRef]

17. Roman, G. Diagnostico Sobre la Generación de Basura Electrónica en México. 2007-a. Available online: http:/ / www.inecc.gob.mx/descargas/diag_basura_electronica.pdf (accessed on 10 December 2016).

18. Roman, G. Desarrollo de un Programa Modelo para el Manejo de Residuos Electrónicos en México. 2007-b. Available online: http://www.inecc.gob.mx/descargas/sqre/2007_inf_plan_manejo_grm.pdf (accessed on 10 December 2016).

19. INECC. Diagnóstico Regional Sobre la Generación de Residuos Electrónicos al Final de su Vida Útil en la Región Noreste de México; SEMARNAT (Ministry of environment): Mexico City, Mexico, 2008. 
20. INECC. Diagnóstico Regional de Residuos Electrónicos en dos Ciudades de la Frontera norte de México: Tijuana y Ciudad Juárez; SEMARNAT: Mexico City, Mexico, 2009.

21. INECC (Instituto Nacional de Ecología y Cambio Climático). Diagnóstico de la Generación de Residuos Electrónicos en la Zona Metropolitana del Valle de México; SEMARNAT: Mexico City, Mexico, 2010.

22. INECC. Diagnóstico Sobre la Generación de Residuos Electrónicos en México; SEMARNAT: Mexico City, Mexico, 2007.

23. INECC (Instituto Nacional de Ecología y Cambio Climático). Análisis de Ciclo de Vida de Residuos Electrónicos y Propuesta de Manejo en Ciudades Fronterizas de Coahuila, Nuevo León y Tamaulipas; Colegio de la Frontera Norte: Mexico City, Mexico, 2012.

24. INECC (Instituto Nacional de Ecología y Cambio Climático). Actualización en la Generación de Residuos Electrónicos en México; SEMARNAT: Mexico City, Mexico, 2014.

25. Alcántara-Concepción, V.; Gavilán-García, A.; Gavilán-García, I.C. Environmental impacts at the end of life of computers and their management alternatives in México. J. Clean. Prod. 2016, 131, 615. [CrossRef]

26. Secretariat of Environment and Natural Resources. Mexican Official Norm NOM-161-SEMARNAT-2011. Available online: http://www.profepa.gob.mx/innovaportal/file/6633/1/nom-161-semarnat-2011.pdf (accessed on 5 November 2016).

27. Zeng, X.; Xu, X.; Boezen, H.M.; Huo, X. Children with health impairments by heavy metals in an e-waste recycling area. Chemosphere 2016, 148, 408-415. [CrossRef] [PubMed]

28. Cui, J.; Zhang, L. Metallurgical recovery of metals from electronic waste: A review. J. Hazard. Mater. 2008, 158, 228-256. [CrossRef] [PubMed]

29. Yunxia, H.; Zhenming, X. The status and development of treatment techniques of typical waste electrical and electronic equipment in China: A review. Waste Manag. Res. 2014, 32, 254-269.

30. Zhang, L.; Zhang, Z. A review of current progress of recycling technologies for metals from waste electrical and electronic equipment. J. Clean. Prod. 2016, 127, 19-36.

31. Zhang, Z.W.; Sun, Y.X.; Sun, K.F.; Xu, X.R.; Yu, S.; Zheng, T.L.; Luo, X.J.; Tian, Y.; Hu, Y.X.; Diao, Z.H.; et al. Brominated flame retardants in mangrove sediments of the Pearl River Estuary, South China: Spatial distribution, temporal trend and mass inventory. Chemosphere 2015, 123, 26-32. [CrossRef] [PubMed]

32. Tang, Z.; Zhang, L.; Huang, Q.; Yang, Y.; Nie, Z.; Cheng, J.; Yang, J.; Wang, Y.; Chai, M. Contamination and risk of heavy metals in soils and sediments from a typical plastic waste recycling area in North China. Ecotoxicol. Environ. Saf. 2015, 122, 343-351. [CrossRef] [PubMed]

33. Official Journal of the Federation (Diario Oficial de la Federación DOF). General Law for the Prevention and Management of Solid Waste. 8 October 2003 (Up-dated: 22 May 2015). Available online: https:/ /www.gob. $\mathrm{mx} / \mathrm{cms}$ /uploads/attachment/file/27266/Ley_General_de_Residuos.pdf (accessed on 3 November 2016).

34. Gavilán-García, A.; Alcántara-Concepción, V. Management proposal, management and disposal of waste electrical and electronic equipment from the government perspective. In E-Wastes Northern Mexico: Challenges and Perspectives for Their Sustainable Management, 1st ed.; González-Ávila, M.E., Ortega-Rubio, A., Eds.; The College of the Northern Border COLEF: Tijuana, Mexico, 2014; pp. 256-293.

35. Official Journal of the Federation DOF. Regulations of the General Law for the Prevention and Management of Waste. (Updated: 31 October 2014). Available online: http://www.diputados.gob.mx/LeyesBiblio/ regley/Reg_LGPGIR_311014.pdf (accessed on 5 November 2016).

36. Secretariat of Environment and Natural Resources. Mexican Official Norm NOM-052-SEMARNAT-2005, Establishes the Characteristics, the Process of Identification, Classification and Listing of Hazardous Waste. México. Available online: http://www.inb.unam.mx/stecnica/nom052_semarnat.pdf (accessed on 5 November 2016).

37. Kiddee, P.; Naidu, R.; Wong, M.H. Electronic waste management approaches: An overview. Waste Manag. 2013, 33, 1237-1250. [CrossRef] [PubMed]

38. Khaliq, A.; Rhamdhani, M.A.; Brooks, G.; Masood, S. Metal Extraction Processes for Electronic Waste and Existing Industrial Routes: A Review and Australian Perspective. Resources 2014, 3, 152-179. [CrossRef]

39. Ortiz, R. Planes de Manejo de Residuos de Electrónicos in Foro Sobre el Ciclo Productivo del Reciclaje de Residuos Electrónicos en México; CANIETI-SEMARNAT-INECC; SEMARNAT: Mexico City, Mexico, 2015.

40. Ojeda, S.; Cruz, S.E.; Jáuregui, J.M. Estudio de Condiciones Actuales y Linea Base para un Proyecto de Residuos Electrónicos en Baja California; COCEF: Mexicali, Mexico, 2015. 
41. Boeni, H.W. Reciclaje Electrónico: El Modelo Suizo. In Proceedings of the Tercer Taller Internacional: Del Reacondicionamiento al Reciclaje de PC, una Oportunidad para LAC, San José, Costa Rica, 13-15 November 2006.

42. Khetriwal, D.S.; Kraeuchi, P.; Widmer, R. Producer responsibility for e-waste management: Key issues for consideration-learning from the Swiss experience. J. Environ. Manag. 2009, 90, 153-165. [CrossRef] [PubMed]

43. United Nations Environment Programme. E-Waste: Management Manual; Division of Technology, Industry and Economics International: Osaka, Japan, 2007; Volume II, p. 127.

44. OECD (Organisation for Economic Cooperation and Development). Extended Producer Responsibility: A Guidance Manual for Governments; OECD: Paris, France, 2001.

45. Tran, H.P.; Wang, F.; Dewulf, J.; Huynh, T.H.; Schaubroeck, T. Estimation of the unregistered inflow of electrical and electronic equipment to a domestic market: A case study on televisions in Vietnam. Environ. Sci. Technol. 2016, 50, 2424-2433. [CrossRef] [PubMed]

(C) 2017 by the authors. Licensee MDPI, Basel, Switzerland. This article is an open access article distributed under the terms and conditions of the Creative Commons Attribution (CC BY) license (http:/ / creativecommons.org/licenses/by/4.0/). 